\title{
THE APPLICATION OF LEAN MANAGEMENT IN HIGHER EDUCATION
}

\author{
Stepha n Höfer*, J örg Naeve**
}

\begin{abstract}
Background. The application of lean management is standard in many companies all over the world. It is used to continuously optimise existing production processes and to reduce the complexity of administrative processes. Unfortunately, in higher education, the awareness of lean management as a highly effective methodology is quite low.
\end{abstract}

Research aims. The research aim is to show how the lean strategy can be applied in university environments. Finally, this paper address the question why it is so difficult to implement lean in a university environment and how an institution of higher education can move forward towards becoming a lean university.

Methodology. Based on a literature review, five key lean principles are presented and examples of their implementation are discussed using short case studies from our own institution. We also compare our findings with those in the literature.

Key findings. Lean offers the chance to improve the management of higher education institutions. This requires a commitment on the part of the university top management aiming at convincing all stakeholders that a culture of lean helps the institution to be able to adapt to the rapidly changing environment of higher education.

Key words: lean management, lean administration, lean house of higher education, lean university, efficiency

\section{INTRODUCTION}

The idea and the application of lean management are nothing new, but this idea is not yet implemented in the field of higher education to the same extent as in production and in service industries. Antony calls

* ESB Business School, Reutlingen University. E-mail: stephan.hoefer@reutlingen-university.de

** ESB Business School, Reutlingen University. E-mail: joerg.naeve@reutlingen-university.de 
it being in "the embryonic stages" (Antony, 2015, editorial note). The hypothesis of this paper is that the strategy of lean management can be applied to solving problems in a university environment. We justify this hypothesis by a multiple case analysis of lean solutions in higher education at our university similar to Waterbury's approach (Waterbury, 2015, p. 934). On the basis of case studies, a literature review, and the personal experience of the authors we propose a lean house of higher education and show how it can be applied to universities management.

\section{LEAN MANAGEMENT IN HIGHER EDUCATION}

Lean management (hereinafter also referred to as "Lean") is a business strategy and not a toolset. Lean is the willingness on each hierarchical level to question one's own behaviour, to learn from mistakes and to continuously develop new solutions towards waste-free processes (see Table 2). Lean stands for permanent customer-focused and value-adding thinking and acting (Womack, \& Jones, 1997, p. 16).

Lean has mainly been developed for and applied in the area of manufacturing. However, various activities have shown that the idea of Lean can be applied in the administrative service sector as well (e.g. Höfer, 2016, p. 189). However, how can it be applied in a very special service sector, that of higher education?

Everywhere, and thus also in higher education, we are confronted with an increasing degree of complexity. In the past, universities were able to focus on their core competencies: research and teaching. However, today, universities are competing in a global market, with a declining number of potential students, and staff members who would gain much higher salaries in the private market. As a consequence, universities now need to become "decathletes" with ten different skills listed in Table 1.

This change towards becoming a decathlete results in a considerable need for flexibility, rapid change, and willingness to change in the organisation. Unfortunately, however, in many universities attitudes like "never change a running system", "we have always done it like that", or "we are a university and not a company" seem to predominate.

To successfully manage change, the following three factors need to be maximised: one should be able to do, willing to do, and allowed to do (Niermeyer, \& Seyffert, 2013, p. 152). The factor "be able to do" 
depends on knowledge, methods and education. The factor "willing to do" depends on motivation and the factor "allowed to do" depends on leadership and the particular structure of an organisation. Lean management helps to improve all three factors in an organisation.

Table 1. Universities as a "decathlete" in higher education

\begin{tabular}{|c|l|}
\hline 1. & Excellence in teaching \\
\hline 2. & Excellence in online distance learning \\
\hline 3. & Excellence in research and development \\
\hline 4. & Excellence in gaining research funds \\
\hline 5. & Excellence in providing service to students \\
\hline 6. & Excellence in managing international partners \\
\hline 7. & Excellence in alumni management \\
\hline 8. & Excellence in cooperation with companies and knowledge transfer \\
\hline 9. & Excellence in ranking management and accreditation \\
\hline 10. & Excellence in self-marketing \\
\hline
\end{tabular}

Source: own work.

\section{The lean house of higher education}

This section presents the lean house of higher education. It will be the basis on which the strategy of lean and the application of lean methods will be discussed.

The roof shows the key goal of lean in higher education, which is to create added value without waste. In production, the distinction between value-adding and waste is quite easy to understand (Protzman, Mayzell, \& Kerpchar, 2010, p. 87):

- If the customer is willing to pay for a task (for example, for the production of an item), it is referred to as being value-adding and it should be the goal to simplify all such tasks to make it easier to create this value.

- Tasks under current methods of operation, for which the customer is not willing to pay, but which are necessary to create the value (like an internal transportation of an item) are called hidden waste and should be minimised.

- If a task is redundant or is the result of a previous failure or defect, it is called obvious waste and should be eliminated. 


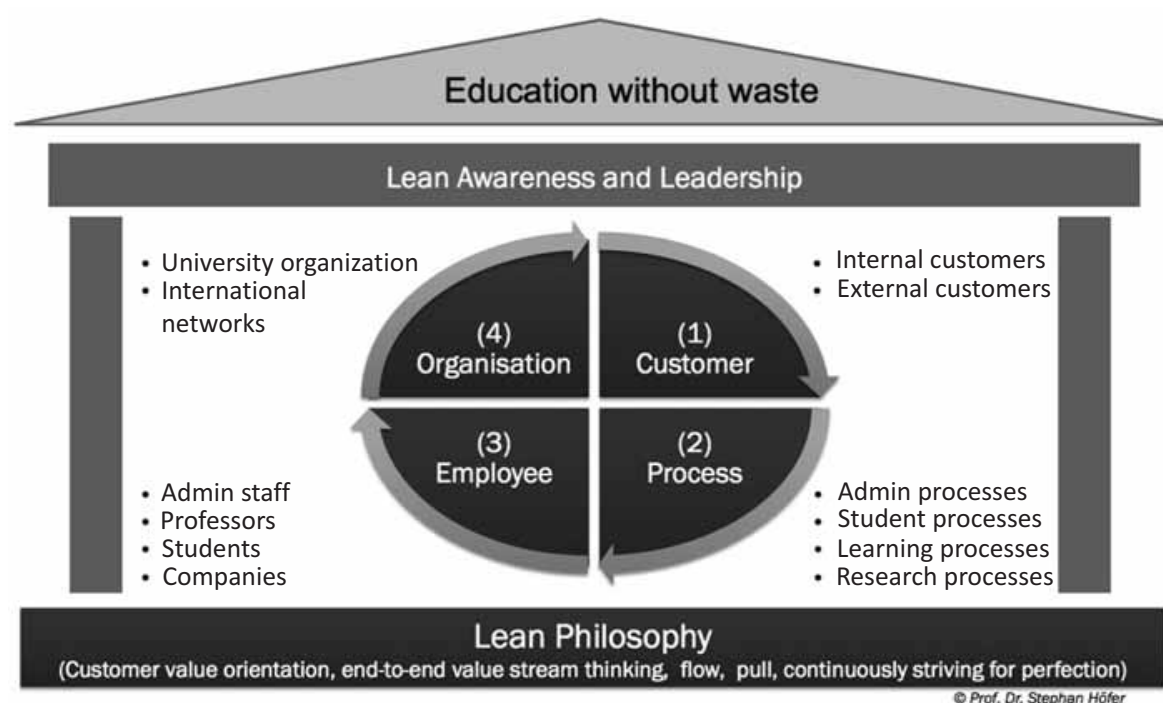

Figure 1. The lean house in higher education

Source: adapted from Höfer, 2016, p. 197.

Analogously, examples of value-adding and waste can be identified in higher education. The basis can be the eight different kinds of waste adapted to higher education institutions as shown by (Douglas, Antony, $\&$ Douglas, 2015, p. 977). However, one has to take into account that many processes do not have only one obvious customer, but various other different customers as well which makes the distinction between value-adding and waste more difficult. This may be illustrated by the example of writing a thesis in an industrial environment. For example, most of our students at ESB Business School write their thesis in cooperation with companies. This creates a triple-win situation for all three partners (students, companies, and the university): It supports knowledge transfer between university and company, students gain theoretical as well as practical experience and expand their personal network, and, in addition, it supports the development of the university to become a decathlete. This process has various customers with a differing perception of added value. Examples of customers, value-adding and waste are given in Table 2.

This list of customers could be extended even further: the research community, the state and the society could also be mentioned as customers. However, from whatever perspective we look at it: any 
kind of obvious waste is a nuisance for those affected and should be eliminated. Hidden waste is necessary but should be reduced as much as possible and value-adding activities should be made as simple as possible to perform. This is what lean stands for.

Table 2. Different customers, different kinds of value-adding

\begin{tabular}{|c|c|c|c|}
\hline $\begin{array}{l}\text { Customers } \\
\text { and their } \\
\text { key goals }\end{array}$ & $\begin{array}{l}\text { Examples of } \\
\text { value-adding }\end{array}$ & $\begin{array}{l}\text { Examples of } \\
\text { hidden waste }\end{array}$ & $\begin{array}{l}\text { Examples of } \\
\text { obvious waste }\end{array}$ \\
\hline $\begin{array}{l}\text { University } \\
\overrightarrow{\text { Reputation }}\end{array}$ & $\begin{array}{l}\text { The student acts as } \\
\text { a positive ambassador } \\
\text { for the university. }\end{array}$ & $\begin{array}{l}\text { The university provides, } \\
\text { technical and labora- } \\
\text { tory infrastructure to } \\
\text { support the student's } \\
\text { research. }\end{array}$ & $\begin{array}{l}\text { The company does not } \\
\text { allow publication of the } \\
\text { outcome of the thesis. }\end{array}$ \\
\hline $\begin{array}{l}\text { Professor } \\
\rightarrow \text { Publica- } \\
\text { tions }\end{array}$ & $\begin{array}{l}\text { The content of the the- } \\
\text { sis is advanced enough } \\
\text { to be published. }\end{array}$ & $\begin{array}{l}\text { The professor writes } \\
\text { an assessment of the } \\
\text { thesis. }\end{array}$ & $\begin{array}{l}\text { Rework is required } \\
\text { due to an incomplete } \\
\text { analysis before it can be } \\
\text { published. }\end{array}$ \\
\hline $\begin{array}{l}\text { Company } \\
\rightarrow \text { Solved } \\
\text { problems }\end{array}$ & $\begin{array}{l}\text { The company benefits } \\
\text { from the knowledge } \\
\text { transfer with the } \\
\text { university. }\end{array}$ & $\begin{array}{l}\text { The contract needs to } \\
\text { be drawn up and the } \\
\text { student needs to be } \\
\text { supervised. }\end{array}$ & $\begin{array}{l}\text { The student fails to } \\
\text { finish his/her thesis. }\end{array}$ \\
\hline $\begin{array}{l}\text { University } \\
\text { staff } \\
\rightarrow \text { Rewarding } \\
\text { job }\end{array}$ & $\begin{array}{l}\text { The staff members } \\
\text { have a well-paid easy } \\
\text { to perform job in a sat- } \\
\text { isfying environment. }\end{array}$ & $\begin{array}{l}\text { The administrative part } \\
\text { of thesis handling has } \\
\text { to be covered. }\end{array}$ & $\begin{array}{l}\text { Requests need to be } \\
\text { answered. }\end{array}$ \\
\hline $\begin{array}{l}\text { Student } \\
\rightarrow \text { The degree }\end{array}$ & $\begin{array}{l}\text { The student gets a } \\
\text { good mark for his/her } \\
\text { thesis and a good job } \\
\text { at that company. }\end{array}$ & $\begin{array}{l}\text { The student has to } \\
\text { travel between universi- } \\
\text { ty and company. }\end{array}$ & $\begin{array}{l}\text { Mismatches between } \\
\text { different customer } \\
\text { expectations cause } \\
\text { redundant work. }\end{array}$ \\
\hline
\end{tabular}

Source: own work.

\section{THE LEAN PRINCIPLES}

James Womack and Daniel Jones (Womack, \& Jones, 1997, p. 15) indicate five core principles of lean:

- Customer and value orientation,

- End-to-end value stream thinking,

- Application of the Flow principle,

- Application of the Pull principle,

- $\quad$ and the continuous pursuit of perfection.

This section indicates examples of implementing the above principles in higher education. 


\section{Customer and value orientation}

If one identifies the customers of a task one can answer more particular questions, for example:

- What exactly does the customer require?

- In which detail is it required?

- At which frequency and in which quantity it is required?

- Can we avoid the customer requiring it at all?

- And if it is required: How can we make it easier to perform this task?

In order to properly answer the above questions, one has to take into account the interests of different customers (compare Table 2) and the customer-supplier relationships at stake.

In the following we illustrate how customer oriented thinking can help by analysing the case of writing a Master's thesis.

\section{Case 1: Lean structure of a thesis}

Students frequently ask about the proper size of their Master's thesis. They have learned so much about the topic that they do not know what to leave out. If students applied the principle of customer orientation, they would frame the structure of their text in terms of customer-supplier relationships. For the sake of simplicity, assume a thesis has only two chapters. Then, Chapter 2 should be seen as the "customer" of Chapter 1 . Before we consider what we should include in Chapter 1 (which is how most students start), we should rather start analysing what the customer of Chapter 2 requires. If we know what to discuss and what insights we want to gain in Chapter 2, we can identify what the reader as the ultimate customer requires in Chapter 1 to be able to understand Chapter 2. Instead of writing purely in forward direction (the author-focused approach), we should use backwards induction starting from the end, from the customer. Figure 2 visualises this for two chapters.

In the lean approach, the aim of the text determines its content, the content of later chapters imply what is needed in the former ones. The reader is the ultimate customer of the text, and its earlier sections should help the reader understand later sections of the text. 
Author-focused

approach

1

Title Chapter 1

Content Chapter 1

So what's Chapter 1

Title Chapter 2

Content Chapter 2

So what's Chapter 2
Customer-focused

approach

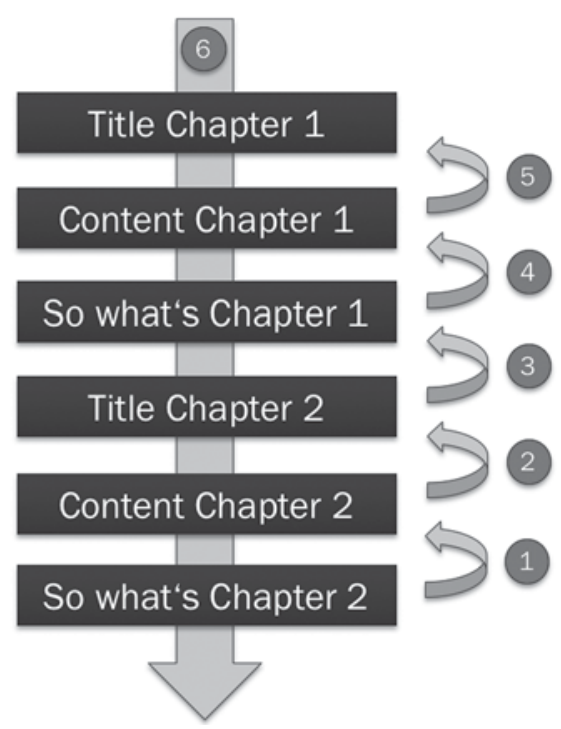

Figure 2. The lean structure of a thesis

Source: own work.

\section{The end-to-end value stream thinking}

Customers perceive the result of a process as a whole, not the result of a single step. Thus, processes need to be analysed end-to-end from the customer's point of view to identify value-adding steps in the process. Obviously, the rest is hidden or even obvious waste. To make it easier to think about processes in higher education in terms of waste, Table 3 lists eight categories of waste which can be distinguished (cf. goleansixsigma.com, n.d.; Douglas et al., 2015, p. 977).

Table 3. The eight different kinds of waste in higher education

\begin{tabular}{|l|l|l|}
\hline $\begin{array}{c}\text { Category of } \\
\text { waste }\end{array}$ & \multicolumn{1}{c|}{ Explanation } & \multicolumn{1}{c|}{ Examples in higher education } \\
\hline $\begin{array}{l}\text { D Defects and } \\
\text { rework }\end{array}$ & $\begin{array}{l}\text { Any kind of re- } \\
\text { quests, loops, and } \\
\text { iterations within } \\
\text { processes }\end{array}$ & $\begin{array}{l}\text { - Requests due to missing information } \\
\text { - Going to the wrong lecture room (iteration) } \\
\text { - Going to a lecture when the professor is ill and } \\
\text { the day's schedule has to be changed (loop) }\end{array}$ \\
\hline
\end{tabular}


Table 3. continued

\begin{tabular}{|c|c|c|}
\hline $\begin{array}{l}\text { Category of } \\
\text { waste }\end{array}$ & Explanation & Examples in higher education \\
\hline $\begin{array}{l}\text { O Over-Produc- } \\
\text { tion }\end{array}$ & $\begin{array}{l}\text { Production of } \\
\text { more than is actu- } \\
\text { ally required }\end{array}$ & $\begin{array}{l}\text { - Study programs which are not full } \\
\text { - Students who apply although they do not fulfil } \\
\text { preconditions to join the program } \\
\text { - Writing a reference for a student who does not } \\
\text { use it }\end{array}$ \\
\hline W Waiting & $\begin{array}{l}\text { Any kind of } \\
\text { delays }\end{array}$ & $\begin{array}{l}\text { - Waiting for capacities/information/missing } \\
\text { approvals/decisions } \\
\text { - Searching for data in the computer } \\
\text { - People coming late for meetings }\end{array}$ \\
\hline $\begin{array}{l}\text { N Non-utilised } \\
\text { Talent }\end{array}$ & $\begin{array}{l}\text { The knowledge, } \\
\text { skills and the } \\
\text { time of employees }\end{array}$ & $\begin{array}{l}\text { - Lack of empowerment } \\
\text { - Unclear responsibilities } \\
\text { - No continuous improvement process }\end{array}$ \\
\hline $\begin{array}{l}\text { T Transporta- } \\
\text { tion }\end{array}$ & $\begin{array}{l}\text { Transport of } \\
\text { material or infor- } \\
\text { mation }\end{array}$ & $\begin{array}{l}\text { - Data transfer and communications } \\
\text { - Managing interfaces } \\
\text { - Email distribution lists }\end{array}$ \\
\hline I Inventory & $\begin{array}{l}\text { Any kind of raw } \\
\text { material, work in } \\
\text { process (WIP) or } \\
\text { finished items }\end{array}$ & $\begin{array}{l}\text { - Computer data structure } \\
\text { - Unprocessed Emails (WIP) } \\
\text { - Old exams which need to be kept }\end{array}$ \\
\hline M Motion & $\begin{array}{l}\text { Movement of the } \\
\text { employee }\end{array}$ & $\begin{array}{l}\text { - The way from the office to the lecture room } \\
\text { - Fragmented office structures } \\
\text { - Messy workplace }\end{array}$ \\
\hline $\begin{array}{l}\text { E Extra } \\
\text { Processing }\end{array}$ & $\begin{array}{l}\text { Unnecessary } \\
\text { working steps }\end{array}$ & $\begin{array}{l}\text { Two signatures to approve a business trip } \\
\text { - Typing grades in an Excel sheet and in the } \\
\text { university system (media changes) } \\
\text { - Unnecessary complexity due to an extended } \\
\text { form of continuous assessment }\end{array}$ \\
\hline
\end{tabular}

Source: adapted from goleansixsigma.com, n.d., with input from Douglas et al., 2015, p. 977.

The following case illustrates this end-to-end value stream thinking in a university.

\section{Case 2: Redesign of the purchasing process of office materials}

Some years ago the first author asked his secretary to order some post-it notes for his lecture. After one month, they had still not arrived. Therefore, the secretary was asked to find out what had gone wrong. It turned out that one person in the process was waiting for an additional request for the same type of post-it notes since the ordered quantity was too low to justify the effort of asking for three bids and creating a purchase order. This was the motivation to initiate a student project to analyse this administrative process end-to-end with the goal to identify and reduce waste. 
Using the method of administrative value stream design (Höfer, 2016, p. 189) the students visualised the current situation together with staff members working in the process. Based on this, they developed and implemented a redesigned value stream with the performance shown in Table 4.

Table 4. The process performance before and after

\begin{tabular}{|l|l|l|}
\hline \multicolumn{1}{|c|}{ Parameter } & \multicolumn{1}{c|}{ Before } & \multicolumn{1}{c|}{ After } \\
\hline Number of involved persons & 8 & 4 \\
\hline Number of solicited bids & 3 & 0 \\
\hline Number of approvals & 3 & 1 \\
\hline Throughput time & Unpredictable & 24 hours for standard office items \\
\hline
\end{tabular}

Source: own work.

This result sounds almost too good to be true but the solution was quite simple. There already existed a catalogue for office articles agreed upon between the state authority and suppliers with a commitment to 24-hour delivery and without the requirement for bid proposals which served as the basis for the new process. The above example shows that also in institutions of higher education, many processes exist, which can be improved by end-to-end administrative value stream analysis and design.

\section{The flow principle}

Material and information should flow. Whenever they stop, they create delays and become inventory (Womack, \& Jones, 1997, p. 15). In higher education it is mainly the information flow that impacts the performance of processes. Case 3 illustrates the flow principle by showing how increasing the flow helps to smoothen processes and to reduce waste also in higher education.

\section{Case 3: E-mail response time}

In almost every feedback meeting between our students and university staff, e-mails are on the agenda: Students frequently complain that professors answer too late, and professors complain, that many students do not read their emails at all. Both are exaggerations, of course, but the problem is real. To address it, this issue has been included in our code 
of conduct (Daxhammer, 2016, p. 4), which has been developed, agreed upon and implemented by professors, students, and administrative staff together. Each new student, professor, lecturer, or staff member receives a copy when entering the organisation. It does not serve as a legal basis for sanctions, but as a framework of reference points based on the key principles of the ESB Business School (Daxhammer, 2016). While we cannot directly measure changes in email response times, having aligned expectations and a common reference point for discussions has significantly reduced the conflict potential and has smoothened the process.

\section{The pull principle}

Pull means that we produce something only if it is actually required. If we produce something on stock, we call it push (Womack, \& Jones, 1997, p. 15).

Although most of the processes in administration are pull by definition (a professor will not write a reference for a student without a request) some processes in higher education are still push and can be converted into pull, as the following case demonstrates.

\section{Case 4: Design of a pull lecture}

Typically, lectures are push. The professor defines what to teach, how to teach, and when. Especially in Master degree courses where students should be competent enough, it can make sense to convert push lectures into pull lectures. ESB Business School offers a unique Master degree program where students work in optimisation projects in industry and attend parallel lectures at the university. The design of the corresponding lean management lecture includes pull: students can ask the professor three days prior to the next lecture to teach a particular topic depending on the kind or the status of the project they are involved in. Also the particular project can be used as a real case study to apply lean methods and tools. This maximises the value for the students: They get what they need when they need it, and they can immediately apply it.

This example shows how the lean idea from push to pull can be applied in the design of a lecture. How lean can be applied to redesign a whole curriculum, the reader is being referred to (Thomas, Antony, Haven-Tang, Francis, \& Fisher, 2017, p. 577). 


\section{Continuously striving for perfection}

Lean stands for delivering exactly the value customers are willing to pay for, when they want it with zero waste (Womack, \& Jones, 1997, p. 15). To achieve lean in a changing environment processes, IT systems, and technology, as well as the way of working need to be continuously adapted towards the current best practice. This requires people who are willing to, allowed to, and be able to do so (Niermeyer, $\&$ Seyffert, 2013, p. 152). The following case demonstrates this striving for perfection in the management of a double degree program.

\section{Case 5: Shop fbor management in a double degree program}

ESB Business School is part of a network of 16 universities from twelve different countries around the world jointly offering unique double degree Bachelor degree programs in international management. In each bilateral link students spend $50 \%$ of their time at one partner university and $50 \%$ at a partner university in another country. To facilitate this, all curricula need to be synchronised. At the same time, local requirements for awarding the degree of the partner universities involved have to be taken into account, which vary quite a bit. This implies that:

- In any one lecture there may be students from up to twelve different countries.

- While based on a common structure, each link has its own special rules to fulfil the local requirements.

- All links need to cooperate and to synchronise not only their organisation but also their way of teaching and their lecture contents.

Therefore, these programs imply a high degree of complexity for staff members, professors, and students alike. It can cause various problems. For example:

- Grades from partner universities are missing,

- A mandatory lecture cannot be offered due to local constraints,

- Students have problems finding an internship.

Some of these problems cannot be solved within a single faculty or university; they need to be solved among two international partners or even the network as a whole. This requires quick reactions from the cooperating partners, as well as a high degree of flexibility and commitment to the needs of the program. 
One of the links (the German-Polish link between the Jagiellonian University in Krakow and ESB Business School) started six years ago. To make this link work both partners established a weekly jour fixe to work on their continuous improvement. In effect this has established a so-called shop floor management (Brunner, 2011, p. 101) for the link: Everybody in both institutions (staff, professors, and students) knows that any problem that may occur will be discussed and hopefully solved by the next Thursday at 2 p.m. The results are quick feedback loops, fewer misunderstandings, continuous problem solving, and less complexity for all participants. It is an exemplification of how the principle of continuously striving for perfection can work in higher education.

\section{THE CHANGE TOWARDS A LEAN ORGANISATION IN HIGHER EDUCATION}

In the centre of the lean house of higher education the process of change towards a lean university is visualised. It starts with an analysis of internal and external customers and their real requirements. The next step is the design of ideally waste-free processes to create added value and to provide the right tools and techniques for the right employees with the right qualifications and the right knowledge. Finally, the organisation needs to be adapted to the new process landscape and the four phases can start again.

Tables 5.1. to 5.4. show questions to be answered during the four phases outlined above and typical lean tools, which can be applied to answer them. Details concerning these tools can be found in the literature indicated in the right frames.

Table 5.1. Step 1. Customer and value analysis

\begin{tabular}{|l|c|}
\hline Customer: Identify the customers need & Examples of tools \\
\hline Who is my customer? & - Classic feedback analyses \\
What does he/she really require? & (Lunau, Merran, John, Staudter, \& \\
In which detail, and at which frequency, & Roenpage, 2012, p. 73) \\
In which quantity and in which quality? & - Value Proposition Methodology \\
How can we avoid him/her requiring it? & (Osterwalder, Pigneur, Bernarda, \& \\
Or maybe not as often? & Smith, 2014, p. 14) \\
Or how can I generate this added value & - Kano Analyses \\
easier? & - Lunau et al., 2012, p. 63 \\
\hline
\end{tabular}

Source: own work. 
Table 5.2. Step 2. Process design

\begin{tabular}{|c|c|}
\hline $\begin{array}{l}\text { Process: Value adding processes free of } \\
\text { waste }\end{array}$ & Examples of tools \\
\hline $\begin{array}{l}\text { What does our process landscape look like? } \\
\text { How can we increase process transparency? } \\
\text { How can we eliminate obvious waste? } \\
\text { How can we reduce hidden waste? } \\
\text { How can we increase value adding? } \\
\text { How can we standardise and visualise best } \\
\text { practices? }\end{array}$ & $\begin{aligned} & \text { - } \text { SIPOC analysis } \\
& \text { (Lunau et al., 2012, p. 35) } \\
& \text { - Order structure analysis } \\
& \text { (Wiegand, \& Franck, 2004, p. 51ff) } \\
& \text { - Value stream analysis and design } \\
& \text { (Höfer, 2016, p. 189) }\end{aligned}$ \\
\hline
\end{tabular}

Source: own work.

Table 5.3. Step 3. Enabling employees

\begin{tabular}{|l|c|}
\hline \multicolumn{1}{|c|}{ Employee: Provide the right tools and skills } & Examples of tools \\
\hline Do we have the right people with the right skills? & - Job breakdown analysis \\
Do we have them in the right position? & (Wiegand, \& Franck, 2004, p. 99) \\
Do they have the right tools? & - Skill matrix \\
Is their workload levelled? & (North, Sieber-Suter, \& Rein- \\
Do working standards exist? & hard, 2013, p. 164) \\
Are those standards controlled and are deviations & - Standardisation and visualisa- \\
detected? & tion, Poka Yoke, Lean Six Sigma, \\
Do the employees contribute to continuous im- & 5S (Lunau et al., 2012, pp. 7, \\
provement? & $270,274,351$ ) \\
\hline
\end{tabular}

Source: own work.

Table 5.4. Step 4. Adaptation of the organisation

\begin{tabular}{|c|c|}
\hline $\begin{array}{l}\text { Organisation: Provide a suitable } \\
\text { infrastructure }\end{array}$ & Examples of tools \\
\hline $\begin{array}{l}\text { Does the structure fit to the processes? } \\
\text { What does the information flow look like? } \\
\text { How is the team performance being measured? } \\
\text { How are interfaces being managed? } \\
\text { How is the lean awareness of the organisation } \\
\text { being measured? } \\
\text { How is the continuous improvement process } \\
\text { being designed? } \\
\text { How is lean know-how being trained and spread } \\
\text { over the organisation? }\end{array}$ & $\begin{array}{l}\text { - Company structure analysis } \\
\text { (Wiegand, \& Franck, 2004, p. 39) } \\
\text { - Information flow Analysis } \\
\text { (Wiegand, \& Franck, 2004, p. 115) } \\
\text { - Gemba Walks } \\
\text { (Kudernatsch, 2013, p. 32) } \\
\text { - Shopfloor Management } \\
\text { (Brunner, 2011, p. 101) } \\
\text { - Hansei } \\
\text { (Gorecki, \& Pautsch, 2014, p. 80) } \\
\text { - Hoshin Kanri } \\
\text { (Kudernatsch, 2013, p. 7) }\end{array}$ \\
\hline
\end{tabular}

Source: own work.

Thus, for all four essential elements, namely customer, process, employee, and organisation there is a large variety of tools and techniques available which can be adapted to the particular needs of institutions of higher education helping it to move towards becoming a lean institution. 


\section{LEAN AWARENESS AND LEAN LEADERSHIP}

All lean activities require high lean awareness of all participants (in the case of institutions of higher education students, staff, professors, companies, and partners) as well as lean leadership (Liker, \& Convis, 2012, p. 13). Based on this (Antony, 2014, p. 260), defines 5 readiness factors for an organisation to apply lean thinking in this environment: Leadership and vision, management commitment and resources, linking lean to universities strategy, customer focus, and selecting the right people. Our experience supports his list of factors: If one is missing, most lean activities become the so-called "one time wonders", and the results may not persist. Complementing his list, we see the following success factors:

a) Lean Culture: "Lean starts with yourself" is one of the key messages of the lean strategy. But this requires that individuals are able to recognise their own failures, to admit them, and to identify them as a potential area for improvement. To facilitate this, an essential task of lean leadership is to convince staff members that problems and mistakes are not considered as threats or as bad in general. Mistakes are chances to improve if we analyse their causes without blaming anybody, search for solutions, and implement them together.

b) Lean Tools: As our little process example in Case 2 has shown, in many cases interfaces offer a high potential for improvement. Simple tools like value stream design for administrative processes (Höfer, 2016, p. 189) can help to gain end-to-end process transparency. This improves understanding of the reasons for waste inside a process and allows the process participants to gain a better understanding of how they can positively influence it. It also helps to reduce the negative impact of functional organisations and to bring the process back into focus.

Continuous improvement: "So many times I have made suggestions to change something, but what happened? Nothing!". Comments like this show why also in higher education Shop Floor Management (Brunner, 2011, p. 101) can be the basis for a continuous improvement as explained in Case 5. Lean oriented universities (e.g. the University of St. Andrews in Scotland) have even established their own lean multipliers who act as lean experts and support university organisation's to implement changes (Aristeuein, 2017). 
Kata: Last but not least, the university management plays the key role in the successful implementation of lean. The challenge is to make it a daily routine to question one's own habits, to identify problems, and to implement changes. Therefore, the managers should take the attitude of "we want it, we support it, we measure it, we celebrate the success, and we give credit to those who implemented the change". This needs to be the message university management continuously communicates into the organisation. If the management is not aware of the importance of this role, the success of Lean will be limited to single success stories, but it will not become sustainable, it will not become natural, and it will not become Kata (patterns which are practiced, so that they become a second nature) (Rother, 2013, p. 87).

\section{CONCLUSIONS}

This study shows that the lean strategy can be applied in the management of higher education. It is not always easy, though. It requires a high degree of persistency and staying power. But lean can be used to provide the organisational framework and to create the required change culture, so that processes and involved stakeholders can adapt quicker to a more and more rapidly changing environment.

Further research is needed to examine whether and how the application of lean does and should differ between private and non-private organisations in higher education. In both cases the question how agile methodologies like Scrum (Nowotny, 2016, p. 91) can be applied as well to support the development of a university towards becoming a lean player in the market of higher education merits attention.

Last but not least, it would be interesting to inquire how it can help to improve the process of learning and creativity being at the heart of higher education and quite different from the management of an institution of higher education.

\section{REFERENCES}

Antony, J. (2014). Readiness Factors for the Lean Six Sigma Journey in the Higher Education Sector. International Journal of Productivity and Performance Management, 63(2), 257-264. 
Antony, J. (2015). Editorial Note for the Special Issue on "Lean Six Sigma for Higher Education”. International Journal of Quality \& Reliability Management, 32(9). Aristeuein, A. (2017). St Andrews Lean Consulting. University of St Andrews, Editor. Retrieved from http://standrewslean.com/about/st-andrews-lean-consulting/. Accessed February 23, 2017.

Brunner, F. (2011). Japanische Erfolgskonzepte. München: Hanser.

Daxhammer, R. (2016). Code of Conduct BSc International Management Double-Degree (IMX). ESB Business School, Reutlingen University Ed. Retrieved from https://relax.reutlingen-university.de/. Accessed March 21, 2017.

Douglas, J., Antony, J., \& Douglas, A. (2015). Waste Identification and Elimination in HEI's:

The Role of Lean Thinking. International Journal of Quality \& Reliability Management, 32(9), 970-981.

goleansixsigma.com (n.d.). Retrieved from http://www.goLeansixsigma.com/8-wastes/. Accessed January 6, 2017.

Gorecki, P., \& Pautsch, P. (2014). Praxisbuch Lean Management: Der Weg zur Operativen Excellence (2nd ed.). München: Hanser.

Höfer, S. (2016). Lean Sales: Steigerung des Wertschöpfungsanteils in Vertriebsprozessen. In: H. Künzel (ed.), Erfolgsfaktor Lean Management 2.0 (pp. 189-208). Heidelberg: Springer.

Kudernatsch, D. (ed.) (2013). Hoshin Kanri: Unternehmensweite Strategieumsetzung mit Lean Management Tools. Stuttgart: Schäffer Poeschel.

Liker, J.K., \& Convis, G.L. (2012). The Toyota Way to Lean Leadership. New York: McGraw-Hill.

Lunau, S., Merran, R., John, A., Staudter, C., \& Roenpage, O. (2012). Six Sigma + Lean Toolset. Heidelberg: Springer Gabler.

Niermeyer, R., \& Seyffert, M. (2013). Mitarbeitermotivation in Veränderungsprozessen. Freiburg: Haufe Lexware.

North, K., Sieber-Suter, B., \& Reinhard, K. (2013). Kompetenzmanagement in der Praxis. Wiesbaden: Springer Gabler.

Nowotny, V. (2016). Agile Unternehmen: Nur was sich bewegt, kann sich verbessern. Göttingen: Business Village.

Osterwalder, A., Pigneur, Y., Bernarda, G., \& Smith, A. (2014). Value Proposition Design: How to Create Products and Services Customers Want (Strategyzer). Hoboken, NJ: Wiley.

Protzman, C., Mayzell, G., \& Kerpchar, J. (2010). Leveraging Lean in Healthcare. Danvers, MA: CRC Press.

Rother, M. (2013). Die Kata des Weltmarktführes: Toyotas Erfolgsmethoden, transl. S. Kienkel. Frankfurt: Campus. 
Thomas, A., Antony, J., Haven-Tang, C., Francis, M., \& Fisher, R. (2017). Implementing Lean Six Sigma into Curriculum Design and Delivery - A Case Study in Higher Education. International Journal of Productivity and Performance Management, 66(5), 577-597.

Waterbury, T. (2015). Learning from the Pioneers: A Multiple-case Analysis of Implementing Lean in Higher Education. International Journal of Quality \& Reliability Management, 32(9), 934-950.

Wiegand, B., \& Franck, P. (2004). Lean Administration 1: So werden Geschäftsprozesse transparent. Aachen: Lean Management Institut.

Womack, J.P., \& Jones, D.T. (1997). Auf dem Weg zum perfekten Unternehmen (Lean Thinking). Frankfurt: Campus. 


\title{
ZASTOSOWANIE LEAN MANAGEMENT W SZKOLNICTWIE WYŻSZYM
}

\begin{abstract}
Abstrakt
Tło badań. Stosowanie lean management stało się standardem w wielu przedsiębiorstwach na całym świecie. Wspiera stały proces ulepszania produkcji, maksymalizację wartości dodanej oraz minimalizację malwersacji, pomaga zredukować złożoność procesów administracyjnych. Niestety niska świadomość efektywności lean management $\mathrm{w}$ kontekście kształcenia na uczelniach wyższych wpływa na to, iż nie odgrywa ono znaczącej roli w obszarze zarządzania powyższymi organizacjami.

Cele badań. W publikacji przedstawiono propozycję stosowania strategii lean management $\mathrm{w}$ środowisku uniwersyteckim. Wskazano także na trudności zwiazane $\mathrm{z}$ implementacją lean management $\mathrm{w}$ uczelniach wyższych, a także opisano, jak instytucje szkolnictwa wyższego mogą rozwijać się w kierunku stania się lean univeristies.

Metodologia. Na podstawie analizy literatury przedstawiono pięć najważniejszych zasad lean management oraz omówiono ich wdrożenie w uczelniach wyższych, z którymi związani są Autorzy tekstu. Dokonano także porównania wybranych case studies związanych z praktyką zawodową autorów z przykładami z literatury.

Kluczowe wnioski. Lean management daje duże możliwości w procesie usprawniania zarządzania w uczelniach wyższych. Jednym z najważniejszych wymogów jest zaangażowanie najwyższych władz uczelni w przekonanie interesariuszy (stakeholders) organizacji, iż wymagana kultura zmiany (culture of lean) stanowi wsparcie uczelni $\mathrm{w}$ adaptacji i elastycznym dostosowaniu się do dynamicznie zmieniającego się otoczenia instytucji szkolnictwa wyższego.
\end{abstract}

Słowa kluczowe: lean management, szczupła administracja, lean house of higher education, lean university, efektywność 